\title{
Nilai Pendidikan Islam pada Upacara Adat Kematian Masyarakat Melayu Landak
}

\author{
Siti Mery Sukarniawati, Hariansyah, wahab \\ Pascasarjana IAIN Pontianak \\ Jl. Letjend Suprapto, Benua Melayu Darat, Kec. Pontianak Sel., Kota Pontianak, \\ Kalimantan Barat Indonesia \\ E-mail: sukarniawatisitimery@gmail.com
}

\begin{abstract}
Loss of culture are eroded by the strong influx of progress time progress, causing forget it cultural in this process there are various kinds of values education local knowledge. When exhumated and learned shall be form the character of students who appropriate to the state of social life in the area.The goal is to dig values education local knowledge to be applied for education. Excavated and found with the use of the qualitative method approach ethnography .So successful of values islamic education that is in a ceremony death the community malay village the king kabupaten porcupine, namely value attitude generous, cultivating charity, strengthening our relationship, reading Qur'an Habbit.Zikir, tahlil, attitude gotong royong, empathy, sympathy, and honor guests habbits .Keywords: the value of islamic education, customary death, malay porcupine
\end{abstract}

Keywords:. the value of islamic education, , customary death , Melayu Landak

\begin{abstract}
Abstrak
Hilangnya budaya yang terkikis oleh derasnya arus kemajuan perkembangan zaman, menyebabkan terlupakannya budaya yang di dalam prosesnya terdapat berbagai macam nilainilai pendidikan kearifan lokal. Apabila digali dan dipelajari maka akan dapat membentuk karakter siswa yang sesuai dengan keadaan kehidupan sosial di lingkungannya. Tujuannya untuk menggali nilai-nilai pendidikan kearifan lokal yang dapat diterapkan pada dunia pendidikan. Digali dan ditemukan dengan penggunaan metode kualitatif pendekatan etnografi. Maka membuahkan hasil berupa nilai-nilai pendidikan Islam yang terdapat dalam upacara kematian masyarakat Melayu Desa Raja Kabupaten Landak, yaitu nilai Sikap dermawan, membudayakan bersedekah, mempererat tali silaturahmi, pembiasaan membaca Al-Qur'an. Berdzikir, bertahlil, sikap gotong royong, empati, simpati, dan pembiasaan menghormati tamu.
\end{abstract}

Kata Kunci: Nilai Pendidikan Islam, Adat Kematian, Melayu Landak 


\section{Pendahuluan}

Derasnya arus globalisasi dan modernisasi yang berdampak kepada pesatnya kemajuan teknologi, dikhawatirkan dapat mengakibatkan lunturnya rasa kecintaan dan kebanggaan terhadap kebudayaan lokal. Sehingga kebudayaan lokal yang merupakan warisan para leluhur tersaingi oleh budaya asing, terbuang dari tempatnya sendiri dan terlupakan oleh para penerusnya, bahkan banyak para penerus generasi yang masih muda tidak mengenali budaya daerahnya sendiri. Mereka lebih bangga kepada budaya barat karya orang-orang asing, dan gaya kehidupan yang kebarat-barattan dibandingkan dengan kebudayaan lokal daerahnya sendiri.

Karena manusia hidup disekitar budaya, maka kebudayaan lokal merupakan kebudayaan yang sangat dijunjung tinggi oleh masyarakat dan selalu berupaya untuk mempertahankan eksistensinya dalam kehidupan. Di mana dalam kebudayaan terdapat kearifan lokal yang dapat dijadikan sebagai pendidikan. Karena kearifan lokal merupakan kebijakan manusia dalam mengembangkan keunggulan lokal yang bersandar pada filosofi nilai-nilai, etika, cara dan perilaku yang melembaga secara tradisional, sehingga apabila dijadikan sebagai sebuah pendidikan memiliki relevansi yang tinggi bagi kecakapan hidup (life skills) dengan mengutamakan pemberdayaan keterampilan dan potensi lokal yang dimiliki oleh masing-masing daerah, di mana ini akan mengajarkan kepada peserta didik untuk selalu dekat dengan situasi yang konkret atau nyata yang mereka hadapi atau dengan kata lain adalah untuk selalu dekat dan menjaga keadaan sekitar yang bersifat nilai yang terdapat dalam budaya lokal masyarakat ${ }^{1}$.

Maka dengan memberikan atau mengenalkan kembali nilai-nilai kearifan lokal akan dapat terus menguatkan budaya lokal agar tidak hilang dan ditinggalkan oleh masyarakat. Dan dapat membentengi dari pengaruh budaya luar yang sebenarnya belum tentu sesuai dengan tantanan dan norma masyarakat lokal. Bahwa kelemahan pendidikan sekarang adalah tidak melihat kearifan lokal, bahkan ada beberapa sekolah yang tidak sama sekali memasukkan kearifan lokal di dalam pembelajarannya. Seharusnya sekolah sebagai lembaga pendidikan, memiliki peran dalam penanaman nilai-nilai kearifan lokal, yang harus digalakkan sebagai kurikulum yang tersembunyi, karena sekolah sebagai lembaga pendidikan berfungsi untuk mensosialisasikan kepada peserta didik untuk mempelajari cara hidup yang sesuai dengan lingkungan hidup mereka, atau lingkungan di mana mereka dilahirkan. Agar sesuai dengan lingkungan masyarakat yang sudah memasuki era globalisasi tetapi tidak dengan meninggalkan kebudayaan. Karena kearifan

${ }^{1}$ Nadlir, "Urgensi Pembelajaran Berbasis Kearifan Lokal," Pendidikan Agama Islam 2, no. 2 (2014): 299-330. 
lokal adalah inti tradisi masyarakat yang diakui sebagai milik bersama, dinilai patut, dikenal makna positifnya, dan terbukti efektif dalam mempertahankan keberlangsungan masyarakat dan menjaganya dari gangguan unsur-unsur yang bisa merusak ${ }^{2}$.

pada intinya adalah bahwa pendidikan kearifan lokal mengajarkan untuk selalu dekat dengan situasi hidup yang nyata, yang terjadi dikehidupan, sehingga dalam menghadapi segala sesuatu permasalahan dapat ditanggapi secara kritis, sehingga menurut Wagiran dalam (Istiawati, 2016:7) bahwa ini merupakan modal untuk pembentukan karakter luhur, yang memiliki arti watak bangsa yang senantiasa bertindak dengan penuh kesadaran dan pengendalian diri, yang berpusat pada upaya meninggalkan hawa nafsu, menimalisir keinginan, dan menyesuaikan dengan empan papan, di mana ini berdasarkan kepada pilar pendidikan kearifan lokal, yaitu membangun manusia berpendidikan harus berlandaskan pada pengakuan eksistensi manusia sejak dalam kandungan, pendidikan harus berbasis kebenaran dan keluhuran budi, menjauhkan dari cara berpikir tidak benar, pendidikan harus mengembangkan ranah moral, spiritual (ranah efektif) bukan sekedar kognitif dan ranah psikomotorik dan sinergitas budaya.

Sebagaimana dahulu, bahwa para wali songo dengan sangat mudah dapat menyampaikan dan menyebarkan ajaran Islam kepada masyarakat yang dikelilingi oleh banyak budaya melalui budaya Jawa dengan memasukkan Islam di dalamnya. Di mana dilakukan pengembangan kebudayaan, sehingga berdampak kepada kehidupan masyarakat, untuk membentuk dan meningkatkan karakter kepribadian yang baik, yang berakhlakul karimah dan dapat membentuk keseimbangan unsur jiwa sebagai manusia yang berdimensi fisik, psikis, sosial, dan spiritual ${ }^{3}$.

Bukti kecilnya yaitu pada masyarakat Melayu Desa Raja Kabupaten Landak memiliki tradisi turun menurun dari para leluhur mereka berupa tradisi adat kematian. Salah satu tradisi adat yang hingga sekarang masih melekat pada masyarakat Melayu Desa Raja Kabupaten Landak. Bahwa antara budaya dan nilai-nilai pendidikan yang terdapat di dalamnya saling berkaitan tanpa menghilangkan unsur-unsur asli dari kebudayaan, bahwa di dalam tradisinya terdapat nilai-nilai pendidikan Islam. Sebagaimana konsep dan tujuan dari pendidikan Islam adalah rangkaian usaha membimbing, mengarahkan potensi hidup manusia yang berupa kemampuan-kemampuan dasar dan kemampuan belajar sesuai dengan nilai-nilai Islam, sehingga

${ }^{2}$ M Arif, “Islam, Kearifan Lokal Dan Kontekstualisasi Pendidikan: Kelenturan, Signifikansi, Dan Implikasi Edukatifnya," Al-Tahrir 15, no. 1 (2015): 67-90.

${ }^{3}$ Y Tajuddin, "Walisongi Dalam Strategi Komunikasi Dakwah," Addin 2, no. 367-390 (8AD). 
terjadilah perubahan dalam kehidupan pribadinya sebagai mahluk individual, sosial serta dalam hubungannya dengan alam sekitar di mana ia hidup" ${ }^{\text {. }}$

Dari serangkaian prosesnya, mulai dari persiapan untuk fardlu kifayah dan persiapan lainnya yang dibantu oleh masyarakat sekitar secara iklhas dan tanpa pamrih yang dikarenakan adanya rasa empati dan simpati, mengerjakan sesuatu tanpa diperintah dan dibayar, sehingga dalam proses ini terjalinlah komunikasi antar warga, dalam rangka mempererat silaturahmi juga. Selain itu seperti dilaksanakannya sholat magrib berjamaah di rumah mayat tujuannya adalah untuk mendo'akan mayat dengan tahlilan, dzikir, baca Yasin dan membaca Al-Qur'an sampai hatam tiga puluh juz selama tujuh hari tujuh malam. Di mana ini dilakukan selain untuk menghibur keluarga yang ditinggalkan, ada maksud lainnya yaitu agar apa yang dilakukan oleh orang yang masih hidup dengan mengkhususkan pembacaan do'a terhadap mayat, mayat mendapatkan pahala dari amal orang lain.

Artinya:

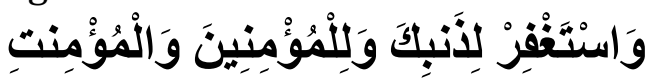

"Dan mohonlah ampunan bagi dosamu dan bagi (dosa) orang-orang mukmin, laki-laki dan perempuan" (QS. Muhammad 47:19). ${ }^{5}$

Bahwa orang yang beriman tidak hanya memperoleh pahala dari perbuatannya sendiri. Mereka juga dapat merasakan manfaat amaliyah orang lain. Dan acara lainnya adalah seperti sedekah yang dilakukan oleh pihak keluarga, ini dilakukan setiap hari selama tujuh hari berturut-turut dan dilanjutkan pada hari tertentu. Untuk sedekah yang dilakukan selama tujuh hari berturut-turut setiap harinya.

Dari beberapa rangkaian acara yang peneliti bahas secara garis besar saja di atas, dari berbagai prosesnya bahwa apa yang dilakukan terdapat nilainilai kearifan lokal di dalamnya. Oleh karena itu peneliti ingin mendeskripsikan tentang nilai-nilai pendidikan Islamnya, melalui proses yang terjadi di lapangan sehingga tradisi ini masih terus dilaksanakan dan dipertahankan oleh masyarakat Melayu Desa Raja Kabupaten Landak.

Dengan pemilihan lokasi yang peneliti pilih yaitu Desa Raja Kabupaten Landak. Selain peneliti merupakan warga penduduk Desa Raja. Desa Raja ini merupakan kampung kerajaan, saksi bisu terjadinya kerajaan Keraton Ismahayana Landak. Dan penduduknya merupakan penduduk keturunan kerajaan yang memiliki nama gelar Ya' atau Gusti (bagi laki-laki), Nyemas atau

\footnotetext{
${ }^{4} \mathrm{MH}$ Salim and E Mahrus, Filsafat Pendidikan Islam (Pontianak: STAIN Pontiianak Press, 2010).

${ }^{5}$ Departermen Agama RI., Mushaf Al-Qur'an Dan Terjemah (Jakarta: PT Pustakak Al-Kausar, 2009).
} 
Utin (bagi perempuan). Penduduknya Melayu dan Muslim semua. Di kampung ini tidak menerima agama non Muslim dan yang memiliki tanah-tanah di kampung Raja tidak boleh dijual kepada orang non Muslim. Karena ini merupakan tanah peninggalan kerajaan. Sehingga diberi nama Desa Raja, Dusun Raja, Kampung Raja Kabupaten Landak.

Sudah selayaknya kita harus giat untuk menggali dan terus mencari kembali nilai-nilai kearifan lokal yang ada agar tidak hilang ditelan oleh perkembangan jaman.

\section{Desa Raja Melayu Landak}

Desa Raja terletak dipinggiran kota Ngabang dan merupakan daerah dataran tinggi, sebagian besar penduduknya bekerja sebagai buruh bangunan, petani dan buruh perkebunan. Desa Raja terletak di Kecamatan Ngabang Kabupaten Landak. Desa Raja memiliki 4 Dusun yaitu, Dusun Raja, Dusun Martalaya, Dusun Raiy, dan Dusun Pesayangan.

Desa Raja terdiri dari 4 dusun, 13 RT, 05 RW dengan jumlah penduduknya, 2.919 jiwa. Yang terdiri dari 1.476 jiwa laki-laki dan 1.443 jiwa perempuan. Dimulai dari usia 0-5 tahun berjumlah 70 orang, usia 6-15 tahun berjumlah 587 orang, usia 16-60 tahun berjumlah 2.054, dan usia 60 tahun ke atas berjumlah 208 orang. (Sumber: Data Demografis Desa Raja Tahun 2017).

Masyarakat Desa Raja adalah masyarakat mayoritas pribumi yang sudah puluhan tahun berdiam di Desa Raja ini, mereka adalah suku Melayu dan suku Dayak, ada sedikit Jawa dan Cina. Mereka hidup dengan rukun dan damai. Dilihat dari segi ekonomi, berkategori sebagai masyarakat menengah kebawah, mayoritas mata pencaharian di Desa Raja ini adalah buruh bangunan, petani dan buruh perkebunan. Adapun komposisi penduduk Desa Raja menurut mata pencahariannya dapat diperincikan, bahwa petani berjumlah 615 orang, wira swasta berjumlah 66 orang, pedagang berjumlah 42 orang, buruh bangunan berjumlah 765 orang, pengrajin/industri kecil berjumlah 69 orang, buruh industri berjumlah 136 orang, PNS berjumlah 186 orang, buruh perkebunan berjumlah 307 orang, dan pensiunan PNS/TNI berjumlah 72 orang (Sumber: Data Sosiografis Desa Raja Tahun 2017).

Dalam segi sosial keagamaan masyarakat Desa Raja masyarakat yang taat dalam melaksanakan ibadah dan kegiatan keagamaan lainnya, hal ini terbukti dengan adanya kegiatan keagamaan seperti kelompok pengajian ibuibu, pengajian bapak-bapak dan TPA yang selalu aktif dalam kegiatannya dan banyaknya tempat ibadah yang dibangun khususnya tempat ibadah agama Islam. Untuk lebih jelasnya dapat dilihat pada tabel 3 berikut ini: 
Tabel

Komposisi Penduduk Menurut Agama

\begin{tabular}{|c|l|l|}
\hline No & \multicolumn{1}{|c|}{ Agama } & \multicolumn{1}{|c|}{ Jumlah } \\
\hline 1. & Islam & 2.438 Orang \\
\hline 2. & Katolik & 265 Orang \\
\hline 3. & Protestan & 216 Orang \\
\hline 4. & Hindu & - Orang \\
\hline 5. & Budha & - Orang \\
\hline
\end{tabular}

Sumber: Data Sosiografis Desa Raja Tahun 2017

Potensi sosial keagamaan Desa Raja berupa lembaga keagamaan dapat dilihat dari beberapa masjid yang berjumlah 3, di mana masjid-masjid ini digunakan secara baik oleh pengurus dalam hal keagamaan, banyak sekali kegiatan yang diselenggarakan setiap tahunnya, ada agenda mingguan, bulanan dan tahunan, seperti acara mingguan setiap subuh dilaksanakannya sajadah fajar yang dilaksanakan secara bergiliran, pelatihan fardhu kifayah, dan kegiatan Islami lainnya, pusat dari semua kegiatan terletak di masjid Jami' Keraton Ismahayana Landak, karena masjid ini merupakan masjid peninggalan kerajaan Landak dan paling terbesar yang ada di Desa Raja, letaknya berdampingan dengan Keraton Ismahayana Landak, tetapi sayangnya bentuk bangunan dan penggunaan kayu-kayu sebagai ciri khasnya sudah di renovasi sedemikian rupa, tetapi tidak meninggalkan corak-corak yang ada pada tekstur masjid sebelumnya. Surau berjumlah 4, dan majlis ta'lim berjumlah 9 kelompok, dalam majlis ta'lim baik para ibu-ibu ataupun bapakbapak sangat aktif dilakukan satu kali dalam seminggu, sehingga tidak ada majlis ta'lim yang lebih terkenal, kalau mengadakan kegiatan mereka selalu bergabung menjadi satu kesatuan, majlis ta'lim ini yang sangat sering melakukan praktek-praktek fardhu kifayah, dengan mendatangkan ahlinya untuk memberikan pelatihan, sehingga ada yang tergerak dan terpanggil untuk menjadi fardhu kifayah dan diberi sertifikat (Sumber: Sosiografis Desa Raja Tahun 2017).

Desa Raja adalah salah satu desa di wilayah Kecamatan Ngabang. Desa ini termasuk golongan masyarakat menengah kebawah, sehingga pelaksanaan administrasi desa cukup baik. Dalam menjalankan administrasi pemerintahan desa cukup baik, dalam rangka memenuhi kebutuhan warga kantor desa selalu terbuka untuk memberikan informasi mengenai masalah-masalah yang berhubungan dengan desa dan pemerintahan. Di kantor desa kepala desa dan stapnya selalu hadir pada jam-jam dinas berlangsung. 
Bahwa penyebaran Melayu di Kalimantan Barat dijabarkan berdasarkan dua kelompok asal-usul, yaitu Melayu asli (Indegenous Malays), kelompok yang Melayu yang telah sangat lama bermukin di Kalimantan Barat atau bisa dikatakan sebagai Melayu pribumi/Melayu setempat/Melayu asli, di mana ini dibagi lagi kedalam empat kategori dan terbagi atas sub pengelompokan, yaitu Melayu Pesisir, Melayu kawasan pedalaman dekat, Melayu kawasan jauh, dan Melayu kawasan peralihan, dan Melayu Landak merupakan bagian sub dari kawasan pedalaman dekat dan Melayu Lama (Proto Melayu)

\section{Ritual Adat Kematian Pada Masyarakat Melayu}

Dalam sebuah jurnal internasional yang ditulis oleh Sumarman Muhammad Djar'ie dan Zaenuddin Hudi Prasojo mengatakan bahwa The ritual of death is part of the traditional customs carried out by the Malay community, in the moments before death, time of death and after death. Ritual kematian adalah bagian dari adat tradisional yang dilakukan oleh masyarakat Melayu, di saat-saat sebelum kematian, waktu kematian dan setelah kematian. Begitu juga yang terjadi pada masyarakat Melayu Desa Raja Ngabang Kabupaten Landak, memiliki beberapa ritual yang turun temurun dari para leluhurnya yang hingga kini masih dilaksanakan dengan baik, sehingga menjadi suatu kebiasaan yang sakral atau yang harus dilaksanakan.

\section{Menjelang Mati}

Menjelang kematian atau tanda-tanda kematian, masyarakat Melayu Desa Raja tidak memiliki keyakinan atau kepercayaan yang dikaitkan dengan adanya kejadian alam. Seperti dengan tanda apabila ada suara burung hantu. Tetapi tidak untuk masyarakat Melayu Desa Raja.

Bahwa untuk masyarakat Melayu Desa Raja apabila ada keluarga atau kenalan yang sudah sakit beberapa hari tetapi tidak sembuh, minimalnya selama tujuh hari tidak ada perubahan, maka mereka meminta bantuan kepada orang yang dianggap pandai atau bisa dalam melihat tanda-tanda kematian seseorang. Berdasarkan hasil wawancara bersama bapak Muslimin, salah satu orang yang dipercayai oleh orang kampung bisa untuk melihat tanda-tanda kematian, bahwa tidak bisa sembarangan dalam melihatnya, ada ilmunya yaitu ilmu kepastian atau ilmu kemautan atau ilmu maut.

Bagaimana cara mengetahui yaitu dilihat dari umurnya, sudah sakit selama tujuh hari atau lebih dengan tidak ada perubahan dari fisik, dan melihat fisiknya dari matanya dengan tanda bahwa mata kecilnya nampak hilang anak matanya sudah sayup atau nunduk.

Khusus untuk yang susah meninggal, disebabkan oleh dua hal, yaitu dosa karena Allah SWT dan dosa karena manusia, seperti salah janji atau ada sesuatu yang di tuntut. Berdasarkan pengalaman dari bapak Muslimin, setiap orang yang susah meninggal, seperti meninggal siang malam hidup kembali, 
atau sebaliknya. Maka ada cara yang digunakan, yaitu namanya disembelih pakai syarat "sembeleh syarat" untuk orang yang memahami, tetapi ada juga yang tidak sukses menggunakan ini. Contohnya ada orang yang menuntut ilmu, mahabbahnya di tanam di badannya atau ilmu hitamnya di tanam di badannya, seperti ilmu kebal, jimatnya di tanam di badan, sehingga susah meninggal. Ada bacaannya tertentu, dan tidak sembarangan orang diberi tahu. Contohnya bapak Muslimin tidak bisa memberi tahu saya apa bacaannya. Kalau mau tahu, belajar secara khusus bersama beliau. Menurut beliau ini bacaan khusus yang tidak bisa diberikan kepada sembarangan orang.

Adapun syaratnya, yaitu ada yang pakai sendok, pakai gayung, pakai akar lalang dan pakai sendok nasi yang terbuat dari kayu, kemudian diletakkan dileher seperti menggorok atau seperti menyembelih hewan, tetapi menggorokknya dengan pelan-pelan saja, hanya sebagai syarat saja, sambil menggorok sambil membaca do'anya atau sumpahnya6. Sumpah atau bacaan yang dilakukan oleh masyarakat berbeda dengan bacaan yang digunakan oleh bapak Muslimin.

Bahwa tujuan masyarakat untuk menanyakan tanda-tanda kematian kepada orang yang dianggap pandai adalah untuk mengumpulkan para sanak saudara dan keluarga, untuk bisa berkumpul agar calon mayat sebelum kepergiannya dapat bertemu sama sanak keluarga untuk bisa meminta maaf, yang pada intinya adalah saling bermaaf-maafan.

Jadi, apabila sudah dikatakan oleh orang pandai bahwa sudah tidak lama lagi hari meninggalnya, maka para keluarga menangasi calon mayat, dengan bahan-bahan seperti langer, serai wangi, daun juang, yang kemudian direbus menjadi satu sehingga mengeluarkan aroma yang wangi dan segar, air tersebut dimandikan ke calon mayat, setelah dimandikan, kemudian dibalur dengan tepung tawar, yang berbahan dari beras ditumbuk kemudian dicampur kunyit, sebelum dibaluri diseluruh tubuh,maka dibacakan do'a terlebih dahulu, do'a yang dibacakan adalah do'a tolak bala dan do'a selamat atau doa mohon ampun.

Tujuan ditangasi dan dibaluri si calon mayat adalah agar calon mayat dalam menghadap atau kembali kepada Tuhannya dalam keadaan yang bersih, suci lahir batin. Anggapan masyarakat bahwa kalau mau menghadap tuhan harus dalam keadaan yang benar-benar bersih dan suci, sebagaimana juga kita hidup di dunia, kalau mau bertemu sama bos atau atasan kita, pastilah berpenampilan yang baik, rapi, bersih, dan pastinya harus wangi dan tampil lebih dari pada hari-hari biasanya. Begitu juga ketika mau menghadap sang Pencipta.

\section{Kematian}

${ }^{6}$ Ketika ditanya do'anya, informan tidak bisa memberitahu, karena do'a yang dibacakan bukan merupakan do'a yang sembarangan. 
Setelah semua proses di atas dilaksanakan, dan telah tibalah ajalnya mayat untuk menghadap sang Penciptanya. Maka ketika mendengar ada yang meninggal dunia maka keluarga dari mayat langsung menghubungi pihak masjid untuk mengumumkan bahwa telah ada yang meninggal dunia, disebutkan nama lengkapnya bin atau bintinya, nama orang tua atau istrinya, jam meninggal dunia dan tempat disemayamkannya mayat. Kemudian pihak keluarga memanggil orang untuk fardlu kifayah. Orang yang ditunjuk sebagai fardlu kifayah menyiapkan semua perlengkapan untuk fardlu kifayah yang dibantu oleh pihak keluarga.

Kemudian para nelayat berdatangan untuk melayat dan membantu proses pemakaman. Tanpa di suruh dan dibayar setelah melihat mayat dan membacakan do'a untuk mayat, maka para nelayat baik bapak-bapak maupun ibu-ibu langsung dengan sendirinya membantu para fardlu kifayah, para sebagian ibu-ibu sibuk dengan penyucukan kembang, sebagian lagi di dapur sibuk dengan masak-memasak makanan untuk dihidangkan setelah pulang pemakaman. Masyarakat tidak perlu diperintah untuk bekerja, tetapi mereka sudah tahu apa yang harus mereka kerjakan.

Barang untuk memandikan, bahan-bahannya air lima macam, air tanah dari tanah kuning, air bedak dari tepung beras, air daun pandan, air langer dengan air kapur barus. Kain batik 4 sampai 5 helai. Sabun. Kedebung pisang lima atau tiga batang, kalau mangkuk satu batang saja. Anyaman bilak dari buloh atau bambu 5. Penyucukan kembang, bahan-bahannya bunga terserah mau bunga apa saja, daun pandan, jarum, benang, gunting, kain putih untuk bikin bantal dengan sarung tangan. Bahan-bahan untuk mengkafan, kain kafan, kapas 17 biji, bubuk cendana, cermin, sisir, pupur, bedak cap nyonya, minyak rambut terserah mau merek apa tapi seringnya orang pakai minyak rambut urang aring dengan minyak wangi merek melati atau duyu. Untuk menghitung hari dari hari pertama sampai keempat puluh, bahan-bahannya kayu, buloh atau bambu dengan kapur sirih.

Adapun makna dari bahan-bahan diatas adalah sebagai berikut, air tanah dari tanah kuning untuk menyucikan najis, air bedak dari tepung beras, air daun pandan, air langer dengan air kapur barus untuk wewangian. Kain batik 4 sampai 5 helai untuk mandi, naik mandi dengan usungan atau nutup jenazah. Sabun untuk membersihkan dari kotoran. Kedebung pisang untuk membaringkan mayat ketika pemandian. Anyaman bilak dari buloh atau bambu 5 untuk alas memandikan mayat. Nyucuk kembang untuk disusun di atas kerenda, fungsi kembang untuk wangi-wangian dengan memperindah kuburan. Kalau dalam adat nyucuk kembang disakralkan bikin menjadi lima macam, ada yang bentuk juadah atau dodol, bentuk bulan, matahari, tasbih dengan ikat pinggang. Nanti disusun keatas kerenda sesuai dengan urutannya, yang paling atas tasbih, ketengah-tengah ikat pinggang. Panjang rangkain 
bunga dari batas pendengarah sampai kaki atau dari telinga sampai kaki. Nyucuk kembang dengan lima macam selain untuk wangi-wangin dengan meperindah, ada filosofinya diibaratkan hidup ini ada manis pahit asam lemak garamnya. Selain nyucuk kembang dibikin juga bantal untuk mayat, bantal dibikin segi empat diisi daun pandan. Bikin kain sarung tangan untuk mardu atau istinja, dibikin bentuk segitiga. Kain kafan untuk mengafani mayat, untuk bikin tali, cawat atau celana dalam, kerudung dengan baju. Masalah baju terserah mau baju gamis atau baju lainnya, tapi zaman sekarang baju gamis. Kapas 17 biji untuk menutup lubang hidung, telinga, kemaluan, pusat, susu, lutut, kaki, muka, bahu dan lubang-lubang tertentu. Untuk telinga dengan hidung harus liat sikon. Bubuk cendana untuk wewangian yang ditabur ke kapas. Cermin, sisir, pupur, bedak cap nyonya, minyak rambut dengan minyak wangi untuk mendandani mayat. Mayat itu diibaratkan sesuatu yang spesial. Kayu dengan kapur sirih untuk menghitung hari dari hari pertama sampai hari keempat puluh.

Setelah selesai nyucuk kembang baru mayat dimandikan. Setelah dimandikan kemudian mayat dikafani, disholatkan, kemudian dimasukkan kedalam kerenda, mayat ditutup dengan kain batik, baru kain khusus mayat dan diatasnya disusun bunga-bunga yang dicucuk sebelumnya. Bunga disusun sesuai urutannya, yang paling atas bunga yang berbentuk tasbih, yang ketengah-tengah bunga yang berbentuk ikat pinggang, yang kebawah baru disusun bunga yang berbentuk bulan, matahari, juadah atau dodol. Sebelum berjalan dibawa ketempat pemakaman, mayat di dalam kerenda didirikan dipegang oleh empat orang, dan para keluarga inti melewati bawah kerenda mayat sebanyak tiga kali secara bergantian, ini dimaksudkan agar para keluarga tidak terbayang dan teringat pada mayat. Kemudian dikebumikan.

Setelah selesai nabur bunga dan nyiram air kekuburan, para keluarga dan masyarakat yang ikut memakamkan tidak langsung pulang, mereka mengadakan do'a bersama dan ada penyampaian dari pihak keluarga mengenai mayat yang isinya tentang permohonan maaf atas segala khilaf yang pernah mayat lakukan, tentang hutang-hutang yang ditinggalkan mayat dan ucapan terimakasih keluarga atas bantuan dari masyarakat sekitar. Dan para warga masyarakat langsung diajak pulang ke rumah keluarga mayat lagi untuk makan bersama sebagai rasa ucapan terimakasih.

\section{Pasca Mati}

Semua proses pembumian mayat selesai, maka mulai berlakulah pantangan-pantangan bagi para keluarga mayat, seperti pantang menjahit maknanya biar kakinya mayat di akhirat tidak di rantai, biar kematian tidak berjurut-jurut atau berturut-turut untuk satu keluarga. Pantang memakan sayur miding, pakis dengan rebung, diibaratkan itu makanan yang tidak enak. Pantang makan sayur nangka, biar tidak bergetah, tidak terhambat, biar mayat 
jalannya lancar. Pantang makan daun-daun biar keluarga yang ditinggalkan tidak layu atau lemah. Dan selma 40 hari tidak boleh keluar, tidak boleh silaturahmi, tidak bisa menerima tamu yang bukan keluarganya, untuk menjaga image dari perkataan-perkataan orang atau di dalam Islam, dikatakan masih masa iddahnya (ini berlaku hanya untuk pasangan suami istri). Pantang tidak boleh nikah juga, harus tiga kali suci, kalau lagi hamil sampai melahirkan. Dan ada juga pantangan ketika mayat disemayamkan, maka para keluarga tidak boleh mencium mayat, ditakutkan air matanya jatuh di mayat. Karena, menururt kepercayaan masyarakat bahwa air mata itu dapat menghambat perjalanan mayat. Maka kalau ingin mencium mayat untuk yang terakhir kalinya, harus dengan tersenyum.

Maka tibalah waktu pada sore harinya, dilanjutkan dengan acara diadakannya sholat magrib dan sholat fidiyah berjamaah di rumah mayat, kemudian dilanjutkan dengan berdzikir, tahlil, berdo'a, pembacaan yasin dan pembacaan Al-Qur'an, ini dilaksanakan sampai hari ke tujuh. Setelah selesai sholat, berdo'a, berdzikir, tahlil, pembacaan yasin dan pembacaan Al-Qur'an para tamu dipersilahkan untuk makan, makanan yang diberi sesuai dengan urutan pembuatan kue-kue yang sudah ditentukan. Para masyarakat sangat antusias ikut berpartisipasi dalam membaca Al-Qur'an. Yang jarang ada waktu untuk membaca Al-Qur'an akhirnya membaca Al-Qur'an juga.

Untuk sedekah yang digunakan, berdasarkan hasil wawancara bersama pak Muhram, bahwa dari hari pertama sampai hari ketujuh, yaitu pada hari pertama bikin bubur kacang hijau dengan nasi lengkap, hari kedua kue tumpur, hari ketiga kue serabi, hari keempat kue seri muka, hari kelima kue kelepon dengan putri mandi, hari keenam pasung jorong, hari ketujuh kue apam.

Hari ketujuh dengan hari keempat puluh ada namanya betungkal, bahanbahannya daun senemu, daun pinang, daun dapat atau tutup bumi, daun paku naik, daun naman, tali rapia, daun kelapa, beras, kunyit, paku, pengibau, benang kuning, tumpi, kayu perda atau kayu kelupa, pucuk ganti, masuyi dengan jerangau. Hari keempat puluh satu ekor kambing bagi yang ada niat untuk mengkekahkan atau punya rezeki lebih.

Adapun makna dari semua sedekah yang diberikan adalah, bahwa pada hari pertama bikin bubur kacang hijau dengan nasi lengkap. Bubur kacang hijau biar dipermudah jalannya mayat menuju alam akhirat, seperti kacang hijau kalau dilempar kena saja air sedikit langsung hidup, mudah hidupnya. Hari kedua kue tumpur pengganti tubuh yang pecah, hari ketiga kue serabi pengganti perut yang pecah, hari keempat kue seri muka pengganti muka pecah, hari kelima kue kelepon dengan putri mandi pengganti mata yang pecah, hari keenam pasung jorong pengganti hidung dengan telinga, hari ketujuh kue apam berakhirnya hari ke tujuh. 
Di dalam penetapan pembuatan kue dari beberapa narasumber yang diwawancarai oleh peneliti seperti ibu Aminah, ada perbedaan dari urutan hari pembuatan kuenya. Dan ada beberapa juga yang berbeda makna dari pembuatan kue tersebut. Setelah peneliti gali secara mendalam apa yang membuat perbedaan adalah bahwa pak Muhram, merupakan orang yang ditunjuk dari keraton Landak dengan diberi gelar dari keraton yang memiliki tanggung jawab terhadap tradisi ini, masih mengikuti Bugis dengan Banjar, di mana inilah titik awal asal muasalnya. Kalau narasumber yang lainnya kenapa berbeda, karena sudah diperbaharui yang sebenar-benarnya Melayu.

Bahwa kalau ibu Aminah untuk sedekah yang digunakan dari hari pertama sampai hari ketujuh, hari pertama bikin bubur kacang hijau dengan nasi lengkap, hari kedua kue tumpur, hari ketiga kue serabi, hari keempat kue seri muka, hari kelima kue kelepon dengan putri mandi, hari keenam pasung jorong, hari ketujuh kue apam.

Adapun maknanya adalah Sedekah hari pertama bikin bubur kacang hijau dengan nasi lengkap. Bubur kacang hijau biar dipermudah jalannya mayat menuju alam akhirat, seperti kacang hijau kalau dilempar kena saja aiir sedikit langsung hidup, mudah hidupnya. Hari kedua kue tumpur pengganti tubuh yang pecah, hari ketiga kue serabi pengganti perut yang pecah, hari keempat kue seri muka pengganti muka pecah, hari kelima kue kelepon dengan putri mandi pengganti mata yang pecah, hari keenam pasung jorong pengganti hidung dengan telinga, hari ketujuh kue apam berakhirnya hari ke tujuh.

Sebenarnya kue apam merupakan kue yang sakral bagi masyarakat, bahwa dahulu kue apam ini seharusnya hanya bisa dinikmati atau dibikin ketika ada yang meninggal saja. Tetapi faktanya bahwa ini sudah menjadi makanan sehari-hari, yang banyak dijual di warung-warung kecil sebagai makanan untuk sarapan.

Kemudian untuk betungkal, berdasarkan hasil wawancara saya bersama ibu Aye Tonden (nama panggilan), yang memiliki nama asli ibu Marhamah, di mana ibu ini merupakan tetua atau orang yang dituakan untuk melakukan betungkal, atau bisa dibilang beliau merupakan pakar betungkal. Karena dalam betungkal sendiri, tidak sembarangan, ada sumpah serapahnya atau do'anya yang menggunakan bahasa daerah Melayu Ngabang Kabupaten Landak, dan do'a-do'a lainnya.

Adapun bahan-bahannya adalah, daun senemu maknanya rezeki mudah bertemu, daun pinang atau daun gerinang maknanya nyaman senang, daun dapat atau tutup bumi maknanya rezeki mudah didapat, daun paku naik maknanya rezeki naik, daun naman untuk mengikat maknanya untuk nyaman senang juga, kalau tiidak ada daun naman boleh diganti dengan tali rapia. Daun kelapa untuk berdo'a dibentuk jadi anyaman lima jari maknanya rukun lima, 
dibentuk bulat juga maknanya biar menyatu semua, paku maknanya mengeraskan semangat, pengibau untuk bekipas ngibaukan penyakit, benang kuning artinya masih adat raja, tumpi untuk nyimpan tepung, kayu perda atau kayu kelupa maknanya mengeraskan semangat.

Betungkal sendiri memiliki makna untuk mengenal keluarga, kenal sepupu, kenal keponakan, kenal kakek, kenal nenek, kenal paman, kenal bibi, yang betungkal hari ketujuh, menggunakan tungkal putih, maknanya adalah supaya mayat tidak mengenal dunia lagi, dikarenakan sudah dibersihkan dan sudah tenang dan nyaman kealam akhirat. Tungkal hari keempat puluh tungkal kuning maknanya biar ketemu di akhirat. Selain itu maknanya biar tehindar dari bala' biar selamat dunia akhirat juga.

Pada proses sedekah dalam pembuatan makanan, bahwa pada hari ketiga para ibu-ibu sudah mulai membuat tapai dari nasi untuk pembuatan kue apam untuk hari ketujuh. Setelah hitungan masuk hari ketujuh keluarga mengadakan bongkar kapan, barang-barang seperti kasur, kain bekas memandikan dan mengafani mayat di jemur dan disedekahkan. Sebelum dibongkar maka harus membaca tawasul dulu untuk mayat. Setelah itu keluarga mengadakan betungkal putih yang boleh ikut betungkal hanya kelurga dekat saja atau keluarga inti yang sedarah.

Dan acara selesai, dilanjutkan kembali pada hari keempat belas, hari kedua puluh lima dan hari keempat puluh, memanggil orang lagi untuk mendo'akan mayat. Biasanya pada hari kedua puluh lima membikin kue serabi dan pada hari keempat puluh bikin kue apam lagi. Pada hari keempat puluh, ba'da sholat subuh ada pembuangan contengan hari dengan maksud terbebasnya semua pantangan dan pembuangan conteng dilempar ke atas bumbung atau ke atas atap, terus nyembur arus dengan maksud melepaskan yang mati ke yang hidup biar tidak suwe atau sial, sebelum dilempar membaca do'a selamat, ayat kursi dan sholawat, setelah itu besapah atau bilang sesuatu kepada mayat. Baru ke makam dan membaca do'a selamat.

Bila ada yang banyak rezeki maka keluarga melakukan pemotongan kambing untuk kekah. Dan biasanya kekah ini dilaksanakan pada hari ketujuh juga. Setelah pulang dari makan maka keluarga melakukan betungkal lagi. Melaksanakan betungkal kuning. Sebelum betungkal, sekiranya 3 hari sebelum hari keempat puluh atau pada hari ke 27 maka pihak keluarga diharuskan bersedekah dahulu atas nama mayat.

Dalam hal pekerjaan tanpa disuruh para ibu-ibu yang datang langsung masuk ke bagian dapur rumah duka. Disitu para ibu-ibu langsung mengambil posisi masing-masing mengerjakan sesuatu yang belum selesai. Ada yang memasak air untuk bikin air, ada yang memasak nasi dan lauk pauk, ada yang bikin kue, ada yang ngelapin piring, bersihkan gelas, dan menyusun barangbarang di tempat yang telah disediakan. Disini terlihat sekali hangatnya 
kekeluargaan diantara masyarakat. Gotong royongnya sangat kompak sekali. Sehingga terjalin tali silaturahmi sesama keluarga maupun sesama masyarakat. Para masyarakat dan keluarga yang kemarin belum sempat datang, pada hari ketiga mereka datang berbondong-bondong untuk silaturahmi. Para kerabat yang sudah lama tidak pernah bertemu akhirnya bertemu, begitu juga para masyarakat.

Dan ini terus berlanjut setiap tahunnya, dengan nama acara ngancor aek (ngucur/nyiram air ke kuburan), ini dilaksanakan setelah hari kelima lebaran atau biasanya seminggu setelah lebaran. Sebelum memulai mengadakan ngancor aek, maka para keluarga terlebih dahulu harus pergi ke makam, dengan membawa bunga dan air untuk membaca do'a dan tahlil di kuburan. Dan acara ini tidak hanya dilakukan oleh para keluarga saja, tetapi para keluarga mengundang ustad atau orang yang pandai dalam membaca do'a untuk memipin pembacaan do'a dan tahlilan, ustad atau orang yang pandai diberi gelar sebagai bilal.

Bahwa dalam pelaksanaan acara ini, ada yang dilaksanakan secara individu dan ada yang membaca secara kelompok. Kalau secara individu, hanya ditujukan kepada satu orang saja. Kalau secara berkelompok membacanya secara bersama, semua dijamakkan do'anya, untuk semua mayat yang ada dikuburan tersebut, setelah selesai pembacaan do'a dan tahlil, maka masing-masing pergi kekuburan keluarganya untuk menabur bunga dan menyiram air di kuburan.

Adapun prosesnya adalah pertama-tama tawasul dulu kepada Nabi, waliwali Allah SWT dan kepada bikhusus mayat, baru dilanjutkan dengan pembacaan yasin dan tahlil disertai do'a-do'a yang lain. Ketika membaca yasin, membacanya secara bersama, tetapi ketika tahlil dan do'a hanya dilakukan oleh bilal. Setelah itu, baru menabur bunga kemudian menyiramkan air di atas kuburan, yang dimulai dari atas atau kepalanya sampai ke bawah atau kakinya, sebanyak tiga kali. Ketika menyiramkan air, ada bacaan yang dibaca ketika menyiramnya, bacaannya berbeda-beda, ada yang membaca shalawat Nabi saja, ada juga yang membaca do'a untuk mayat "Allahummag firlahaa warhamhaa wa'aafihaa wa'fu anhaa” untuk mayat perempuan, maka kalau untuk laki-laki akhirannya diganti ha. Setelah selesai acara di kuburan, maka dilanjutkan kembal di rumah keluarga mayat, yaitu pembacaan do'a lagi bikhusus untuk mayat, yang dilanjutkan dengan acara makan-makan secara bersama, dengan menggunakan presmanan. Adapun makanan yang tersaji tergantung kemampuan tuan rumah yang mengadakan acara, tetapi kebanyakan adalah menggunakan nasi lengkap.

Adapun makna dari penggunaan air adalah selain untuk membasahi kuburan, air itu mengandung zat yang dibutuhkan, dan air ini dipercaya juga dapat meringankan dosa mayat, karena airnya sudah dibacakan do'a, seperti 
do'a tolak bala. Tetapi makna sesungguhnya menurut informan adalah, bahwa menurut kepercayaan masyarakat AIR itu memiliki makna, kalau huruf A itu Agama, huruf I itu Ilmu, dan huruf R adalah Ridho Allah SWT, semga air yang dikucurkan ke kuburan Allah SWT meridhoi mayat, dan dapat menyinari dan menyertai arwahnya. Kalau makna dari bunga adalah hanya sekedar untuk wewangian saja. Dan makna dari ngancor aek adalah untuk mendo'akan mayat, bahwa apa yang kita sedekahkan, mayat dapat merasakannya juga.

\section{Nilai Pendidikan Islam}

Pendidikan, kebudayaan dan masyarakat mempunyai keterkaitan yang berkenaan dengan suatu hal yang sama ialah nilai-nilai yang terkandung di dalamnya. Nilai-nilai tersebut perlu dilestarikan dan dilaksanakan oleh seluruh penerus generasi kebudayaan. Dalam konteks pendidikan, tradisi merupakan isi pendidikan yang bakal diwariskan generasi tua kepada generasi muda dan generasi seterusnya, sehingga terus berlanjut. Sebab dasar pendidikan Islam tidak dapat dihindari dari perannya manusia, alam dan ilmu Manusia harus mencari ilmu yang terdapat disekitar alamnya dengan menggunakan akal dan nalarnya. Sehingga lahirlah ilmu-ilmu yang bersumber dari manusia dan alam. Sebagaimana firman Allah SWT dalam (QS. alGasyiyah:17-20)

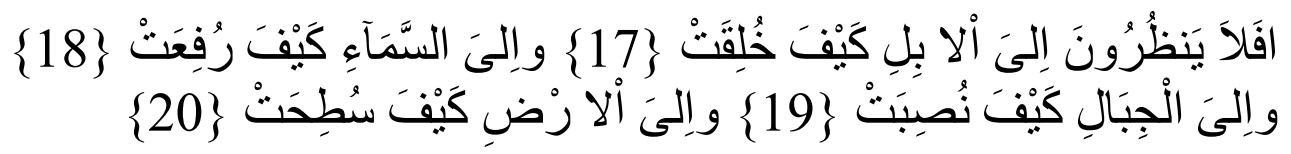

Artinya:

"Apakah mereka tidak mengamati unta bagaimana ia diciptakan, dan langit bagaimana ia ditinggikan, dan gunung-gunung bagaimana dipancangkan, dan bumi bagaimana dihamparkan",

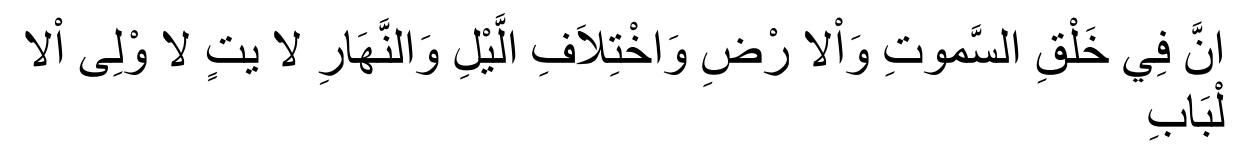

Artinya:

"Sesungguhnya pada ciptaan langit dan bumi dan perbedaan malam dan siang terdapat ayat-ayat (tanda-tanda kekuasaan Allah SWT) bagi mereka yang berakal" (QS. Al-Imran:190) ${ }^{8}$

\footnotetext{
${ }^{7}$ Departermen Agama RI., Mushaf Al-Qur'an Dan Terjemah.

${ }^{8}$ Departermen Agama RI.
} 
Pendidikan Islam adalah rangkaian usaha membimbing, mengarahkan potensi hidup manusia yang berupa kemampuan-kemampuan dasar dan kemampuan belajar sesuai dengan nilai-nilai Islam, sehingga terjadilah perubahan dalam kehidupan pribadinya sebagai mahluk individual, sosial serta dalam hubungannya dengan alam sekitar dimana ia hidup ${ }^{9}$

Dalam menggali nilai-nilai pendidikan Islam dapat dilakukan melalui pendidikan formal, informal dan nonformal. Oleh karena itu, sangatlah diperlukan pendidikan Islam yang dapat dilakukan melalui jalur nonformal melalui tradisi yang ada dalam masyarakat untuk mencapai tujuan pendidikan terutama tujuan pendidikan Islam. Menurut Imam Ghazali dalam Mas'ud10, tujuan pendidikan Islam adalah kesempurnaan manusia yang berujung taqarrub (mendekatkan diri) kepada Allah SWT dan kesempurnaan manusia yang berujung kepada kebahagiaan dunia dan kesentosaan akhirat.

Menurut Ahmad Janan Asifuddin dalam Sutrisno dan Albarobis ${ }^{11}$ jika dikaitkan dengan tujuan penciptaan manusia, setidaknya ada empat tujuan hidup manusia, yaitu:

a. Untuk mengabdi atau beribadah kepada Allah SWT, sebagaimana difirmankan dalam Al-Qur'an:

Artinya:

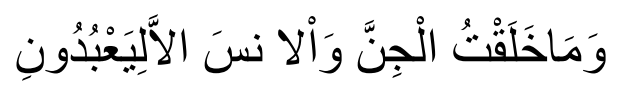

"Aku tidak menciptakan jin dan manusia melainkan agar mereka beribadah kepada-Ku” (QS. Al-Dzariyat:56) ${ }^{12}$

b. Untuk menjadi khalifah Allah SWT di bumi, sebagaimana firman Allah SWT dalam ayat:

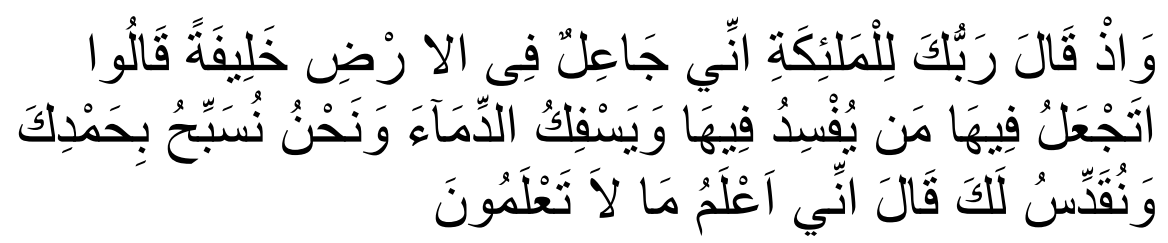

Artinya:

"Dan (ingatlah) ketika Tuhanmu berkata kepada para malaikat, Aku hendak menjadikan khalifah di bumi. Mereka berkata, apakah Engkau hendak menjadikan orang yang merusak dan menumpahkan darah di sana, sedangkan kami bertasbih memuji-Mu dan menyucikan nama-

\footnotetext{
${ }^{9}$ Salim and Mahrus, Filsafat Pendidikan Islam.

${ }^{10}$ Salim and Mahrus.

${ }^{11}$ Sutrisno and M Albarobis, Pendidikan Islam Berbasis Problem Sosial (Jakarta: Ar-Ruzz

12 Departermen Agama RI., Mushaf Al-Qur'an Dan Terjemah.
} Media, 2012). 
Mu ?. Dia berfirman, sungguh Aku mengetahui apa yang tidak kamu ketahui" (QS. Al-Baqarah:30) ${ }^{13}$

c. Untuk mendapatkan ridha Allah SWT, sebagaimana firman-Nya:

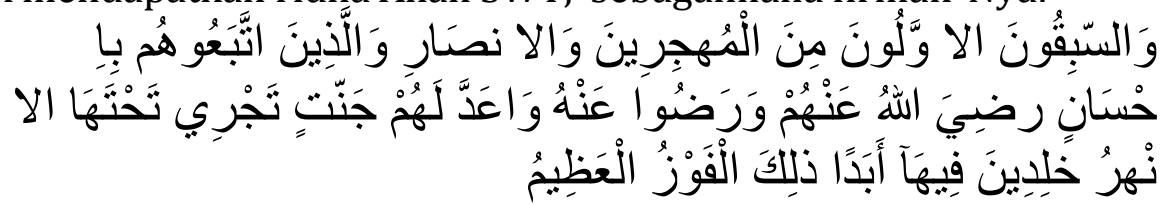

Artinya:

"Dan orang-orang yang terdahulu lagi yang pertama-tama (masuk Islam) di antara orang-orang Muhajirin dan Anshar dan orang-orang yang mengikuti mereka dengan baik, Allah SWT ridha kepada mereka dan merekapun ridha kepada Allah SWT. Allah SWT menyediakan bagi mereka surga-surga yang mengalir di bawahnya sungai-sungai. Mereka kekal di dalamnya selama-lamanya. Itulah kemenangan yang agung" (QS. Al-Taubah:100) $)^{14}$

d. Untuk meraih kebahagiaan hidup di dunia dan akhirat, sebagaimana termaktub dalam Al-Qur'an (QS. Al-Baqarah:201-202)

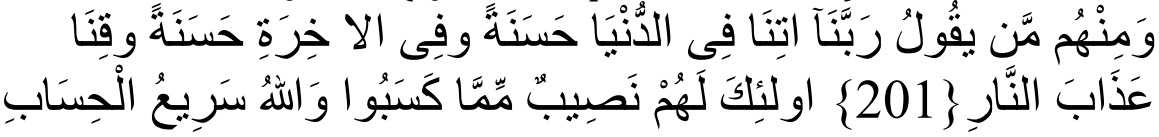

$\{202\}$

Artinya:

"Dan diantara mereka ada yang berdo'a, ya Tuhan kami, berilah kami kebaikan di dunia dan kebaikan di akhirat dan lindungilah kami dari azab neraka. Mereka itulah yang memperoleh bagian dari apa yang telah mereka kerjakan, dan Allah SWT maha cepat perhitunganNya ${ }^{15}$

Tujuan pendidikan Islam yang sesungguhnya adalah menciptakan manusia muslim yang berilmu pengetahuan tinggi, dimana iman dan takwanya menjadi pengendali dalam penerapan atau pengalamannya dalam masyarakat manusia, yang mana pada tujuan akhirnya adalah membentuk kemampuan dan bakat manusia agar mampu menciptakan kesejahteraan dan kebahagiaan yang penuh rahmat dan berkat dari Allah SWT diseluruh penjuru alam ini ${ }^{16}$.

Dari beberapa pendapat para ahli di atas mengenai tujuan pendidikan Islam dapat disimpulkan bahwa tujuan pendidikan Islam adalah untuk membentuk manusia yang beriman, bertakwa, berilmu dan berahlak mulia

\footnotetext{
${ }^{13}$ Departermen Agama RI.

${ }^{14}$ Departermen Agama RI.

${ }^{15}$ Departermen Agama RI.

${ }^{16}$ Arifin, Filsafat Pendidikan Islam (Jakarta: PT Bumi Aksara, 2010).
} 
sepanjang hayatnya sesuai dengan tuntunan Islam. Dan pastinya menjadi sebaik-baiknya khalifah di muka bumi ini dengan menjalankan segala perintah-Nya dan menjauhi segala larangan-Nya.

Sumber pendidikan Islam dapat berasal dari kebiasaan-kebiasaan sosial yang yang dilaksanakan oleh masyarakat sehingga ada nilai-nilai seperti pada upacara adat kematian yang dilaksanakan oleh masyarakat Melayu Desa Raja. Dari data-data di atas berdasarkan keterangan peneliti yang diperoleh dari wawancara dan observasi terhadap informan, setelah peneliti kumpulkan ternyata banyak sekali makna yang terkandung dalam upacara adat kematian yang berkaitan dengan nilai-nilai pendidikan Islam. Secara rinci akan dipaparkan sebagai berikut:

\section{1) Mendidik Untuk Bersikap Dermawan dan Membudayakan Bersedekah}

Ketika mendengar ada yang meninggal dunia di lingkungan tempat tinggal, maka para masyarakat datang untuk pergi nelayat dengan membawa beras sebanyak $2,5 \mathrm{~kg}$. Selain beras bisa juga diganti dengan uang sebagaimana harga beras yang kita makan sebanyak 2,5 kg tetapi ini tidak diwajibkan, lebih utamanya seiklhas kita memberi.

Dari sedekah para nelayat maka dibikin makanan. Berupa hidangan yang disajikan untuk para nelayat yang berdatangan dimaksudkan selain sebagai sedekah tetapi juga sebagai rasa terimakasih karena sudah mau meluangkan waktu untuk membantu melancarkan proses pelaksanaan tradisi. Dan juga rasa syukur telah diberi nikmat berupa rezeki yang lebih, berupa beras dan uang dari para nelayat.

Kemudian rezeki yang berlimpah itu dari pada mubadzir maka dibikin makanan dengan mengajak para masyarakat yang ikut andil dalam proses pelaksanaan acara menikmati rezeki bersama. Dalam kehidupan, setiap mahluk Allah SWT berhak untuk merasakan karunia-Nya. Karunia dan anugerah yang diberikan tidak untuk dinikmati oleh sebagian orang saja, tetapi untuk seluruh umat manusia.

Oleh karena itu pembiasaan sikap dermawan dan bersedekah adalah sangat dianjurkan dalam Islam untuk mewujudkan rasa kasih sayang serta persaudaraan sesama muslim.

\section{2) Mempererat Tali Silaturahmi}

Dalam upacara adat kematian adalah sebagai ajang silaturahmi di mana dalam pelaksanaannya para masyarakat berkumpul, membaur dan bercengkrama satu sama lainnya tanpa memandang suku, budaya, harkat dan martabat. Pada saat inilah mereka dapat berkumpul diluar kesibukan mereka. Sebagaimana firman Allah SWT dalam Al-Qur'an surat Annisa:1 


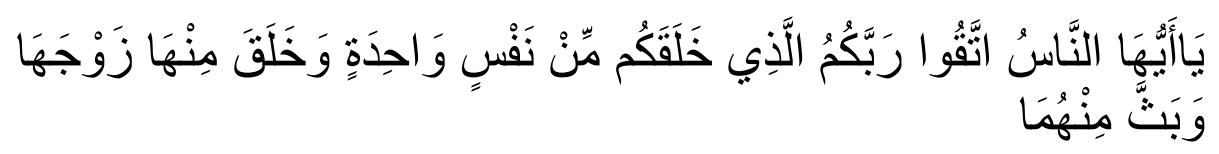

Artinya:

"Hai sekalian manusia, bertakwalah kepada Tuhanmu yang telah menciptakan kamu dari diri yang satu dan dari padanya Allah SWT menciptakan isterinya; dan dari pada keduanya Allah SWT memperkembang biakkan laki-laki dan perempuan yang banyak. Dan bertakwalah kepada Allah SWT yang dengan (mempergunakan) nama-Nya kamu saling meminta satu sama lain dan (peliharalah) hubungan silaturahmi. Sesungguhnya Allah SWT selalu menjaga dan mengawasi kamu" "17

Sabda Rasulullah SAW

Artinya:

"Dari Anas ra dia berkata: Nabi bersabda, barang siapa perpanjang rezekinya dan diperpanjang usianya maka hendaklah dia bersilaturahmi", (H.R. Bukhari, Muslim Nasai)

Bahwa jelas pelaksanaan upacara adat kematian memang terlihat menuju arah perbaikan hubungan antara sesama muslim, sehingga akan menciptakan keharmonisan dan persaudaraan sesama muslim.

\section{3) Membudayakan Membaca Al-Qur'an, Berdzikir dan Bertahlil}

Dalam dunia ini, setiap aspek kehidupan manusia bisa dijadikan sebagai sarana belajar dan sumber untuk mendapatkan ilmu. Demikian juga dengan tradisi yang ada dalam suatu masyarakat dapat dijadikan sebagai sarana yang baik bagi generasi penerus. Salah satu tradisi yang dianggap mengandung unsur pembelajaran adalah tradisi adat kematian yang sampai saat ini masih tetap dilaksanakan.

Dalam pelaksanaan tradisi adat kematian salah satu kegiatan intinya adalah membaca yasin, membaca Al-Qur'an sampai khatam 30 juz, berdzikir dan bertahlil. Pembacaan Al-Qur'an dilakukan setiap malam selama tujuh hari berturut-turut. Secara tidak langsung ini dapat menumbuhkan rasa keterbiasaan dalam membaca Al-Qur'an. Oleh karena itu tradisi adat kematian dapat dikatakan sebagai sarana pembelajaran bagi generasi penerusnya untuk membiasakan diri membaca Al-Qur'an. Tidak hanya membaca Al-Qur'an disaat ada orang meninggal saja, tetapi terus berkelanjutan sampai akhir hayat, ini yang sangat diharapkan dari pelaksanaan tradisi.

\footnotetext{
${ }^{17}$ Departermen Agama RI., Mushaf Al-Qur'an Dan Terjemah.
} 
Selain itu, ada juga berdzikir dan bertahlil yang dimaksudkan agar apa yang dilakukan oleh orang yang masih hidup dengan mengkhususkan pembacaan do'a terhadap mayat, mayat mendapatkan pahala dari amal orang lain.

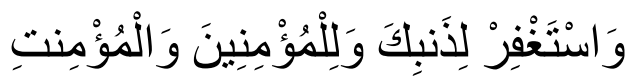

Artinya:

"Dan mohonlah ampunan bagi dosamu dan bagi (dosa) orang-orang mukmin, laki-laki dan perempuan” (QS. Muhammad 47:19). ${ }^{18}$

Bahwa orang yang beriman tidak hanya memperoleh pahala dari perbuatannya sendiri. Mereka juga dapat merasakan manfaat amaliyah orang lain. Tradisi adat kematian yang dilakukan oleh masyarakat sebagai sarana untuk membiasakan diri membaca Al-Qur'andan berdzikir ini terlihat dari semangat masyarakat yang datang setiap harinya ke rumah mayat untuk membaca Al-Qur'an dan berdzikir. Sehingga mereka terbiasa untuk terus membaca Al-Qur'an dan berdzikir.

\section{4) Menumbuhkan Sikap Gotong Royong, Empati dan Simpati Terhadap Sesama}

Dalam proses pelaksanaan tradisi adat kematian juga peneliti menemukan unsur-unsur kerja sama, rasa simpati dan empati, dimulai dari persiapan pelaksanaan sampai selesainya, para nelayat yang datang juga ikut membantu tanpa disuruh-suruh, mulai dari mempersiapkan pemandian, pengkafanan, penguburan dan proses lainnya setelah penguburan dilakukan secara iklhas.

Dari pernyataan informan di atas jelaslah bahwa dari tradisi adat kematian ini dapat diterapkan dalam kehidupan bermasyarakat yang lebih luas lagi, kehidupan yang bermasyarakat, berbangsa dan bernegara. Sikap gotong royong yang dilakukan masyarakat Desa Raja dalam kehidupan seharihari dilingkungannya seperti acara pernikahan, khitanan, khatam Al-Qur'an, pindah rumah, kerja bakti di masjid dan acara-acara lainnya.

Mereka saling membantu demi berjalan dengan lancar acaranya. Membantu dengan sifat kekeluargaan sehingga yang tampak adalah keakraban persaudaraan yang sangat tinggi, karena apa yang dilakukan tidak mengharapkan imbalan apapun, melakukannya dengan iklhas dan hanya mengharapkan ridho Allah SWT. Firman Allah SWT dalam Al_Qur'an surah AlMaidah:2

\footnotetext{
${ }^{18}$ Departermen Agama RI.
} 


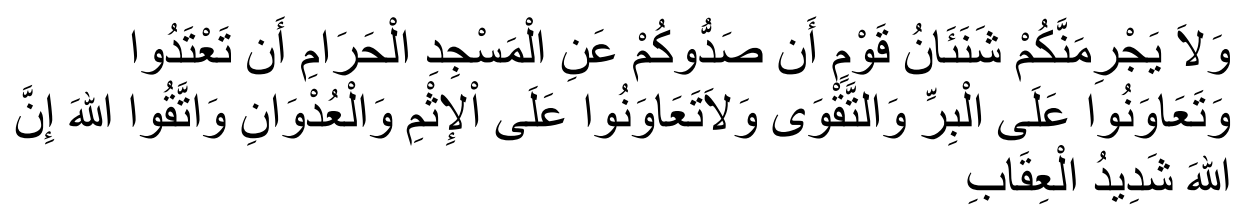

Artinya:

“... Dan janganlah sekali-kali kebencian (mu) kepada suatu kaum karena mereka menghalang-halangi kamu dari masjidil haram, mendorongmu berbuat aniaya (kepada mereka). Dan tolong menolonglah kamu dalam (mengerjakan) kebajikan dan takwa dan janganlah tolong menolong dalam berbuat dosa dan pelanggaran. Dan bertakwalah kamu kepada Allah SWT sesungguhnya Allah SWT amat berat siksa-Nya" 19

Dari ayat di atas dapat diambil sebuah kesimpulan, bahwa Allah SWT menganjurkan kita untuk saling tolong menolong dalam kebaikan antara sesama manusia. Jika kita lihat dalam pelaksanaan tradisi adat kematian adalah suatu perbuatan yang mengajarkan kebaikan yaitu saling tolong menolong atau saling bergotong royong antar sesama untuk kepentingan sesama pula, memiliki rasa empati dan simpati.

\section{5) Membiasakan Diri Menghormati Tamu}

Jika dilihat orang yang ikut dalam pelaksanaan tradisi adat kematian adalah para masyarakat yang meluangkan waktunya disela-sela kesibukannya, yang datang semua tingkatan kalangan menengah, atas dan bawah, mereka merupakan tamu yang perlu dihargai dan dihormati. Walau dalam keadaan acara yang sedih.

Dalam hal menghormati tamu tuan rumah harus sebisanya menyambut dengan ramah dan senyum yang manis. Dengan adanya tradisi adat kematian ini dapat melatih masyarakat dalam kondisi yang bagaimanapun menghormati tamu tentunya harus menyambut dengan ramah dan wajah yang selalu dihiasi dengan senyuman.

Jika tamu merasa dihargai dan dihormati, maka tamu akan merasa senang dan tidak akan segan-segan untuk membantu dan datang lagi untuk membantu pelaksanaan tradisi. Penghormatan terhadap tamu sangat dianjurkan, dalam penghormatan tamu tidak hanya ketika ada pelaksanaan acara saja. Akan tetapi juga harus berlangsung ketika menghormati tamu yang datang ke rumah

${ }^{19}$ Departermen Agama RI. 


\section{Penutup}

Dari upacara adat kematian yang melalui proses dengan serangkaian kegiatan yang melibatkan seluruh warga kampung, terdapat nilai-nilai pendidikan Islam seperti Mendidik Untuk Bersikap Dermawan dan Membudayakan Bersedekah, mempererat tali silaturahmi, Membudayakan Membaca Al-Qur'an, Berdzikir dan Bertahlil, Menumbuhkan Sikap Gotong Royong, Empati dan Simpati Terhadap Sesama, dan Membiasakan Diri Menghormati Tamu

\section{Daftar Pustaka}

Arif, M. "Islam, Kearifan Lokal Dan Kontekstualisasi Pendidikan: Kelenturan, Signifikansi, Dan Implikasi Edukatifnya.” Al-Tahrir 15, no. 1 (2015): 6790 .

Arifin. Filsafat Pendidikan Islam. Jakarta: PT Bumi Aksara, 2010.

Departermen Agama RI. Mushaf Al-Qur'an Dan Terjemah. Jakarta: PT Pustakak Al-Kausar, 2009.

Nadlir. "Urgensi Pembelajaran Berbasis Kearifan Lokal." Pendidikan Agama Islam 2, no. 2 (2014): 299-330.

Salim, MH, and E Mahrus. Filsafat Pendidikan Islam. Pontianak: STAIN Pontiianak Press, 2010.

Sutrisno, and M Albarobis. Pendidikan Islam Berbasis Problem Sosial. Jakarta: Ar-Ruzz Media, 2012.

Tajuddin, Y. “Walisongi Dalam Strategi Komunikasi Dakwah.” Addin 2, no. 367390 (8AD). 